
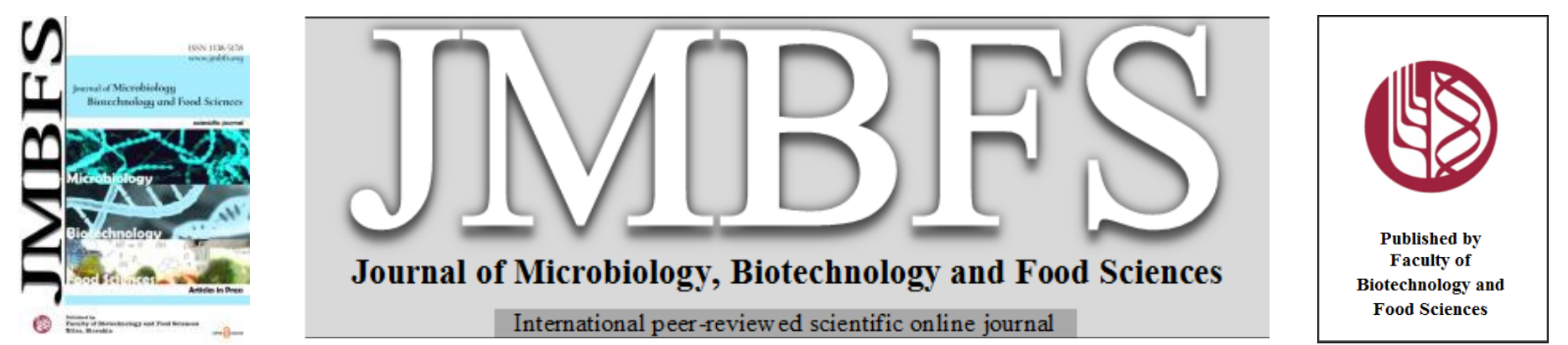

\title{
EFFECT OF DI-(2-ETHYLHEXYL) PHTHALATE (DEHP) EXPOSURE ON MICROARCHITECTURE OF FEMORAL BONE IN MALE LABORATORY MOUSE: PRELIMINARY RESULTS
}

\author{
Eva Šulková, Ramona Babosová*, Branislav Kolena, Zuzana Poláčiková, Henrieta Hlisníková, Miroslava Šidlovská, Mária \\ Vondráková, Monika Martiniaková, Ida Petrovičová
}

Address(es): RNDr. Ramona Babosová, $\mathrm{PhD}$.

Constantine the Philosopher University in Nitra, Faculty of Natural Sciences, Department of Zoology and Anthropology, Nábrežie mládeže 91,94974 Nitra, Slovak Republic.

*Corresponding author: rbabosova@ukf.sk

https://doi.org/10.55251/jmbfs.4435

\section{ARTICLE INFO}

Received 5. 3. 2021

Revised 13. 8. 2021

Accepted 2. 9. 2021

Published 1. 2. 2022

Short communication open $\mathcal{O}$ Access

\begin{abstract}
Di-2-ethylhexyl phthalate (DEHP) is a toxic and hazardous endocrine disruptor with adverse effects on animal and human health. However, its impact on bone tissue has not been sufficiently investigated. Therefore, the purpose of our preliminary study was to examine the effects of DEHP on compact bone structure in two 57-days-old male mice. Daily oral administration of DEHP (4.5 mg/kg body weight dissolved in $500 \mu \mathrm{l}$ of peanut oil per 15 days) was studied, compared to a control. We observed a significant effect of DEHP exposure on macroscopic bone characteristics. Similarly, we identified differences in qualitative characteristics, such as the presence of resorption lacunae and absence of non-vascular and primary vascular radial bone tissue near the endosteal border, compared to the control. On the contrary, quantitative analysis showed no demonstrable alterations in morphometric parameters. Our preliminary findings support the hypothesis about the negative impact of DEHP on bone tissue. However, further investigation is needed to understand this issue better and more precisely.
\end{abstract}

Keywords: di-(2-ethylhexyl) phthalate; endocrine disruptor; compact bone; mouse; behavior

\section{INTRODUCTION}

Phthalates are added in the polyvinyl chloride (PVC) manufacture and act as plasticizers to increase the elasticity, persistence, and longevity of plastic products including cosmetics, medical equipment, food packaging, children's toys, and clothing (Richardson et al., 2018). These compounds are man-made chemicals and work as endocrine disruptors due to their similar structure with steroid hormones (Hlisníková et al., 2020). Among them, the most commonly used member, di-(2-ethylhexyl) phthalate (DEHP) (Rowdhwal and Chen, 2018) represents a serious threat to humans health and the environment (Dong et al., 2020). Tripathi et al. (2019) state that its production increases yearly by $5 \%$ due to growing production demand worldwide. DEHP is compound non-covalently bound to PVC, therefore it can easily release into the environment and cause ambient air, food, water and soil pollution (Dong et al., 2020; Ernst et al., 2020). Organisms can absorb DEHP mainly through ingestion and also through skin contact and inhalation (Rusyn et al., 2016).

Tolerable daily intake was set by European union on $37 \mu \mathrm{g} / \mathrm{kg}$ of body weight (Lo et al., 2014) and estimated daily human exposure is $3-30 \mu \mathrm{g} / \mathrm{kg} /$ day (Hannon $\boldsymbol{e}$ al., 2016). Health-related effect is associated with endocrine toxicity, hepatotoxicity, testicular toxicity, neurotoxicity, cardiotoxicity, reproductive toxicity, teratogenicity of DEHP (Kamijo et al., 2007; Rowdhwal and Chen, 2018) and also in adipogenesis where acts as an obesogen (Schaedlich et al., 2018).

The toxic potential of DEHP is large due to the metabolic transformation into more toxic metabolites by hydrolysis (mono-(2-ethylhexyl) phthalate (MEHP)) and subsequent oxidation reactions (mono-(2-ethyl-5-hydroxyhexyl) phthalate $(5-\mathrm{OH}$ MEHP), mono-(2-ethyl-5-oxo-hexyl) phthalate (5-oxo-MEHP), mono-(2-ethyl-5carboxypentyl) phthalate (5-cx-MEHP)). Secondary oxidized DEHP metabolites (5-OH-MEHP, 5-oxo-MEHP, 5-cx-MEPP and mono-[2-(carboxymethyl) hexyl] phthalate (2-cx-MMHP)) are most valuable biomarkers of DEHP exposure (Koch et al., 2006; Eljezi et al., 2017). Despite the fact DEHP and its metabolites are rapidly excreted from the body (Barakat $\boldsymbol{e t}$ al., 2017), their widespread use and therefore the constant presence in the environment increase the concern about numerous adverse effects on organisms (Herrero et al., 2017).
The studies in rodents have established that estrogens and androgens are locally activated or catabolized within target tissues such as bone (Vandenput $\boldsymbol{e t}$ al. 2016). These hormones contribute to the maintenance of bone mass during adulthood, primarily by slowing bone remodeling rate. They also attenuate the apoptosis of osteocytes, and estrogen or androgen deficiency increases the prevalence of osteocyte apoptosis in both cancellous and cortical bone in animals and humans (Tomkinson et al., 1997; Kousteni et al., 2002; Almeida et al., 2017).

Various animal experiments found possible interference of phthalates also with the bone remodeling process and metabolism. Phthalates have been observed to have an inhibitory effect on osteoblasts in mice, thereby affecting bone mineral density (BMD), along with weak estrogenic, antiestrogenic, and anti-androgenic activity (Agas et al., 2013; DeFlorio-Barker and Turyk, 2016; Fan et al., 2020).

Gestational exposure to phthalate esters causes a sequence of abnormalities in rat pups including elongated and fused ribs (bilateral and unilateral), absence of tail bones, abnormal or incomplete skull bones, and incomplete or missing leg bones (US Environmental Protection Agency, 2021). Chiu et al. (2018) present that the oral administration of DEHP may affect the homeostasis between osteoblastogenesis and adipogenesis and further alter the BMD and microstructure, which is mainly contributed by its primary metabolite MEHP. DEHP, the so-called environmental estrogen (Kanno et al., 2004), can mimic the structure of the endogenous ligand, interfering with the action of the hormone or affects the activities of both androgen and estrogen receptors (Park et al., 2019). Although bones are the target organs of great significance for estrogen, the effects of DEHP (as an endocrine disruptor) on bone histomorphometry has not been sufficiently described yet. In this study, we evaluated the changes in femoral bone microarchitecture in the adult male after 15-days of oral administration of DEHP. Secondary, possible changes in the behavior of experimental animal due to DEHP exposure were observed.

\section{MATERIAL AND METHODS}

The experiment was carried out on two 21-days old male Swiss mice from one litter. After 3 weeks of quarantine, the mice were divided into two groups. Mouse 
from the experimental group was orally administrated DEHP (Sigma-Aldrich, USA) at $4.5 \mathrm{mg} / \mathrm{kg}$ body weight (b.w.) dissolved in $500 \mu \mathrm{l}$ of peanut oil (Biopurus, Germany) per 15 days. The dose of DEHP was chosen as the dose in which no statistically significant adverse effect on the body was observed in other studies compared to the control group (NOAEL DEHP $=4.5 \mathrm{mg} / \mathrm{kg} \mathrm{b.w.)}$ ) estimated by ATSDR (EFSA, 2019). The DEHP solution was made every day and calculated based on the equation:

$$
\mathrm{V}_{\mathrm{DEHP}}=\frac{\operatorname{dose} * \mathrm{~m}}{\rho} * 1000[\mu \mathrm{l}]
$$

where the dose is $4.5 \mathrm{mg} / \mathrm{kg}$ b.w., $\rho=0.981 \mathrm{~g} / \mathrm{cm}^{3}$ at $25^{\circ} \mathrm{C}$ and $\mathrm{m}$ is the daily weight of the mouse (Haynes, 2014). Mouse from the control group was orally administered on sponge cake (adjusted according to Degroote $\boldsymbol{e t}$ al. (2014)) at the same time by $500 \mu 1 /$ animal-vehicle (peanut oil). Animals were housed in individual per cage $\left(800 \mathrm{~cm}^{2}\right)$ and under specific pathogen-free conditions at environmental temperature $21 \pm 3^{\circ} \mathrm{C}$ and $55 \pm 10 \%$ relative humidity (datalogger UNI-T UT330B USB (UNI-T, Guangdong, China)) with a constant photoperiod of $12 \mathrm{~h}$ daylight. Mice were administrated with water and diet on ad libitum base. Experimental breading, handling and conditions were in accordance with Slovak republic Regulation 377/2012 (laying down requirements for the protection of animals used for scientific or educational purposes), with Decree 436/2012 (laying down details of requirements for the protection of animals used for scientific or educational purposes), with Regulation 432/2012 (laying down requirements for the protection of animals at the time of killing). The study received approval of the Institutional Review Board of Constantine the Philosopher University in Nitra.

Behavior of both mice before starting the experiment and throughout its realization (feeding, drinking, grooming, movement and potential presence of pain) were observed and compared according to study Langford et al. (2010).

The experiment ended after 15 days (57 days of age) by cervical dislocation of both mice. Right femoral bones were weighed by analytical scales; length was measured by a digital caliper with precision to $0.01 \mathrm{~mm}$. Analyzed bones were macerated, degreased, and embedded in epoxy resin Biodur (Günter von Hagens, Germany). Thin sections $(70-80 \mu \mathrm{m})$ from femurs were prepared according to the methodology of Martiniaková et al. (2006). Histological sections of all bones were observed and photographed using a polarizing microscope (Leica DM 2000+, Germany) at 50x and 100x magnifications. The qualitative characteristics of the compact bone tissue were determined according to the classification system (Enlow and Brown, 1956; Ricqles et al., 1991)

The quantitative parameters of the compact bone tissue were assessed using the software Motic Images Plus 2.0 ML (Motic China Group Co., Ltd., Xiamen, China). We measured area, perimeter, maximum and minimum diameter of Haversian canals and osteons in all views (i.e., cranial, caudal, medial, and lateral) of thin sections to minimize statistical differences in the individual.

Differences in quantitative parameters were tested for statistical significance by $\mathrm{T}$ test using SPSS 17.0 software (SPSS Inc.; Chicago, Illinois, USA). The normality of data was tested using the Shapiro-Wilk test. Levene's test was used for homogeneity of variances testing. All data were expressed as mean \pm standard deviation and were considered statistically significant when $\mathrm{p}<0.05$.

\section{RESULTS}

Our study brings pilot results from the pre-research phase, which was affected by the pandemic situation of Covid-19. Repetition of further analysis on a larger animal group size, therefore, could not be realized. Because of this, we present a preliminary real analysis of individuals.

Based on macroscopic analysis, we observed increase of femoral length in the control mouse $(16.75 \mathrm{~mm})$ comparing to DEHP-exposed individual $(16.19 \mathrm{~mm})$. On the other hand, the femoral weight of control mouse was lower $(0.0741 \mathrm{~g})$ in comparison to the bone of experimental mouse $(0.0760 \mathrm{~g})$.

Qualitative histological characteristics of the compact bone were almost identical in both analyzed mice. The non-vascular bone tissue as a basic structural pattern of the rodent femurs formed endosteal and periosteal surfaces. Also, near the endosteal surface, we observed a primary vascular radial bone tissue (formed by branching or non-branching vascular canals radiating from the marrow cavity) in pars cranialis of the control mouse. Haversian and non-vascular bone tissues composed the middle part of the compact bone. In pars medialis, the non-vascular bone tissue with rare presence of osteons was observed (Figure 1).

A subacute oral administration of DEHP induced an occurrence of few resorption lacunae in pars lateralis. Similarly, we noticed an absence of primary vascular radial bone tissue in pars cranialis and non-vascular bone tissue in pars lateralis of the endosteal border (Figure 2), compared to the control animal (Figure 1)
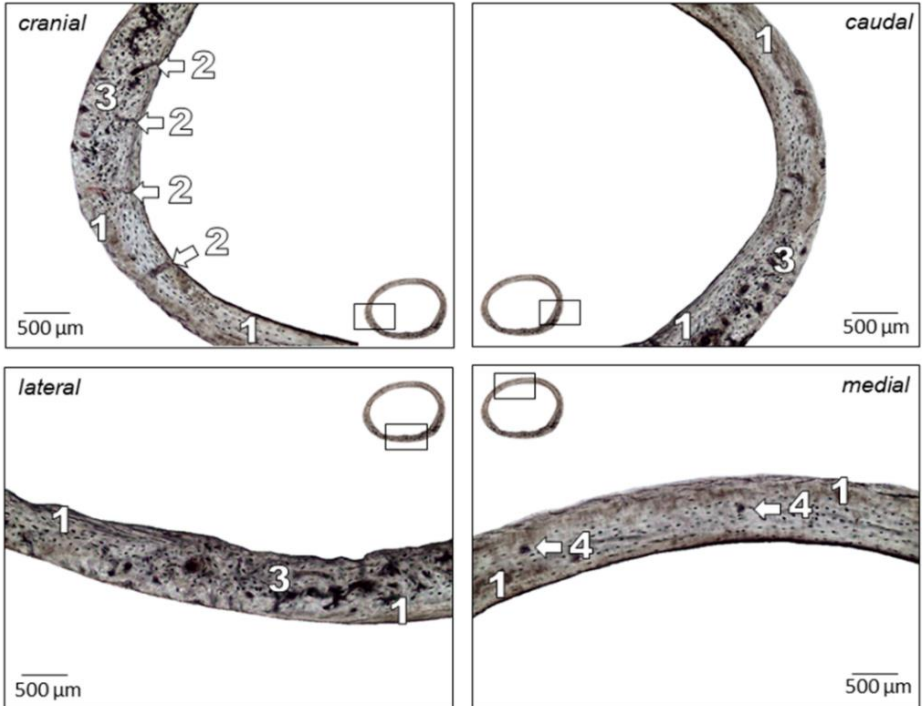

Figure 1 Microstructure of compact bone tissue of control mouse: 1 - non-vascula bone tissue, 2 - primary vascular radial bone tissue, 3 - Haversian bone tissue, 4 - intact osteons
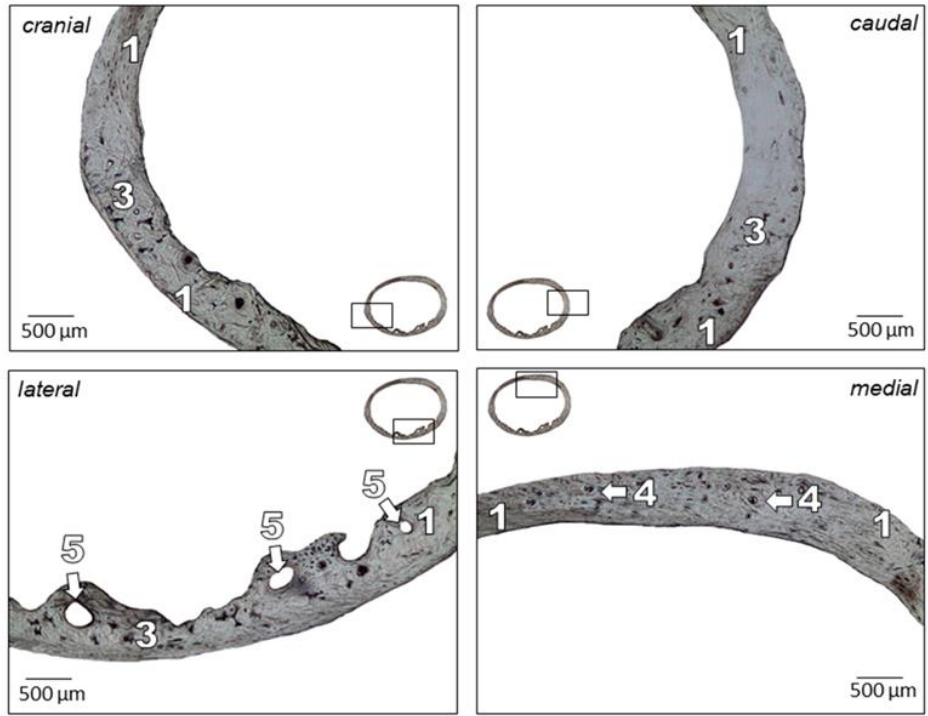

Figure 2 Microstructure of compact bone tissue of exposed mouse: 1 - nonvascular bone tissue, 2 - primary vascular radial bone tissue, 3 - Haversian bone tissue, 4 - intact osteons, 5 - resorption lacunae

In total, Haversian canals $(\mathrm{n}=40)$ and osteons $(\mathrm{n}=40)$ underwent a metric analysis In quantitative analysis we observed non-significant effect of DEHP exposure in all measured parameters (area, perimeter, maximal and minimal diameter) of Haversian canals and osteons between control and experimental sample. The results are summarized in Tables 1 and 2 .

The overall average of Haversian canals for the control sample was $6.6 \pm 0.3 \mu \mathrm{m}$ and for the exposed sample $6.6 \pm 0.4 \mu \mathrm{m}$. According to the classification of Haversian canals (Rämsh and Zerndt, 1963; Gladuhsew, 1964), the osteons of both analyzed samples belong to the category of very narrow Haversian canals.

Overall average of osteons acquired the value of $19.2 \pm 1.4 \mu \mathrm{m}$ in the control and $18.8 \pm 1.3 \mu \mathrm{m}$ in the exposed sample.

In the present study, we also observed the side finding - the potential effect of DEHP exposure on mouse behavior. Comparing the behavior of animals, we had noticed a change of food intake after exposure to DEHP in experimental animal, manifested by refusing food. This had resulted in the decrease in the weight Average weight had reached statistically significantly lower value $(\mathrm{p}=0.0001)$ in experimental animal $(\mathrm{m}=30.373 \pm 1.608 \mathrm{~g})$ in comparison to the control $(\mathrm{m}=$ $33.026 \pm 1.616 \mathrm{~g}$ ) (Figure 3). 
Table 1 Data of Haversian canals (mean \pm standard deviation)

\begin{tabular}{|c|c|c|c|c|c|c|}
\hline Observed files & sample & $\mathbf{n}$ & $\begin{array}{c}\text { area } \\
\left(\mu \mathrm{m}^{2}\right)\end{array}$ & $\begin{array}{c}\text { perimeter } \\
(\mu \mathrm{m})\end{array}$ & $\begin{array}{c}\text { max. diameter } \\
(\mu \mathrm{m})\end{array}$ & $\begin{array}{c}\text { min. diameter } \\
(\mu \mathrm{m})\end{array}$ \\
\hline \multirow{3}{*}{ cranial } & control & 5 & $34.3 \pm 6.0$ & $21.1 \pm 1.8$ & $7.6 \pm 0.3$ & $5.8 \pm 0.3$ \\
\hline & exposed & 5 & $36.7 \pm 3.8$ & $22.4 \pm 1.1$ & $8.4 \pm 0.3$ & $5.6 \pm 0.4$ \\
\hline & T-test & & NS & NS & NS & NS \\
\hline \multirow{3}{*}{ lateral } & control & 5 & $35.7 \pm 3.5$ & $21.2 \pm 0.9$ & $7.0 \pm 0.3$ & $6.6 \pm 0.3$ \\
\hline & exposed & 5 & $34.0 \pm 6.2$ & $20.8 \pm 1.9$ & $7.2 \pm 0.5$ & $6.0 \pm 0.3$ \\
\hline & T-test & & NS & NS & NS & NS \\
\hline \multirow{3}{*}{ medial } & control & 5 & $31.5 \pm 5.9$ & $20.3 \pm 1,8$ & $7.4 \pm 0,3$ & $5.4 \pm 0.3$ \\
\hline & exposed & 5 & $30.6 \pm 1.2$ & $20.6 \pm 0.4$ & $7.8 \pm 0.3$ & $5.0 \pm 0.3$ \\
\hline & T-test & & NS & NS & NS & NS \\
\hline \multirow{3}{*}{ caudal } & control & 5 & $31.5 \pm 5.9$ & $20.4 \pm 1.8$ & $7.4 \pm 0.4$ & $5.4 \pm 0.3$ \\
\hline & exposed & 5 & $27.4 \pm 4.5$ & $18.8 \pm 1.5$ & $6.6 \pm 0.3$ & $5.4 \pm 0.3$ \\
\hline & T-test & & NS & NS & NS & NS \\
\hline
\end{tabular}

Table 2 Data of osteons (mean \pm standard deviation)

\begin{tabular}{llccccc}
\hline Observed files & sample & $\mathbf{n}$ & $\begin{array}{c}\text { area } \\
\left(\boldsymbol{\mu m}^{\mathbf{2}}\right)\end{array}$ & $\begin{array}{c}\text { perimeter } \\
(\boldsymbol{\mu m})\end{array}$ & $\begin{array}{c}\text { max. diameter } \\
(\boldsymbol{\mu m})\end{array}$ & $\begin{array}{c}\text { min. diameter } \\
(\boldsymbol{\mu} \mathbf{m})\end{array}$ \\
\hline \multirow{3}{*}{ cranial } & control & 5 & $232.9 \pm 71.6$ & $54.5 \pm 7.7$ & $18.8 \pm 1.2$ & $15.6 \pm 1.8$ \\
& exposed & 5 & $343.4 \pm 84.6$ & $65.5 \pm 8.4$ & $22.2 \pm 1.3$ & $19.6 \pm 1.5$ \\
& T-test & & $\mathrm{NS}$ & $\mathrm{NS}$ & $\mathrm{NS}$ & $\mathrm{NS}$ \\
\hline \multirow{3}{*}{ lateral } & control & 5 & $377.1 \pm 95.6$ & $68.4 \pm 10.1$ & $22.4 \pm 2.0$ & $21.2 \pm 1.3$ \\
& exposed & 5 & $263.4 \pm 91.5$ & $57.0 \pm 9.0$ & $18.4 \pm 1.5$ & $17.8 \pm 1.4$ \\
& T-test & & $\mathrm{NS}$ & $\mathrm{NS}$ & $\mathrm{NS}$ & $\mathrm{NS}$ \\
\hline \multirow{3}{*}{ medial } & control & 5 & $305.8 \pm 57.8$ & $62.5 \pm 6.7$ & $21.4 \pm 1.8$ & $18.2 \pm 0.7$ \\
& exposed & 5 & $204.7 \pm 27.6$ & $51.7 \pm 3.4$ & $18.6 \pm 0.6$ & $14.0 \pm 0.6$ \\
& T-test & & $\mathrm{NS}$ & $\mathrm{NS}$ & $\mathrm{NS}$ & $\mathrm{NS}$ \\
\hline \multirow{3}{*}{ caudal } & control & 5 & $249.2 \pm 72.0$ & $55.7 \pm 8.3$ & $18.6 \pm 1.4$ & $16.8 \pm 1.3$ \\
& exposed & 5 & $309.7 \pm 96.0$ & $61.9 \pm 8.3$ & $20.6 \pm 2.0$ & $18.8 \pm 1.6$ \\
\hline
\end{tabular}

Legend: $\mathrm{n}$ - number on- measurements; NS - non-significant differences

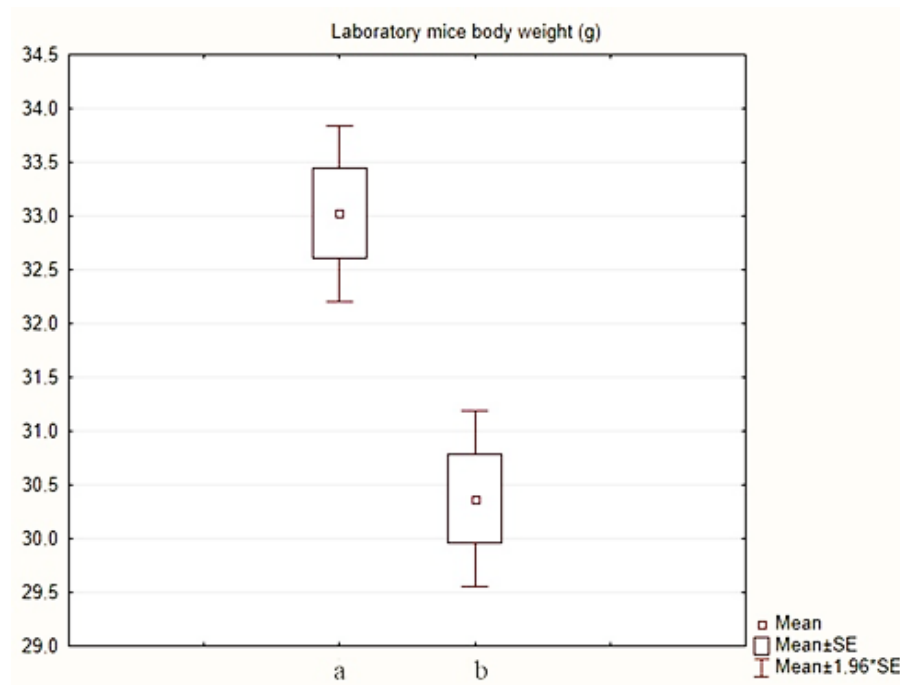

Figure 3 Average weight of control (a) and DEHP-exposed (b) mouse

Coprophagy had been observed only in DEHP exposed individual. We also had observed a noticeable increase in water intake and grooming, apathy and lethargy, and the presence of pain (moderate nose bulge, orbital tightening, rapid breathing, hunched body position) in DEHP-exposed individual.

\section{DISCUSSION}

In current study, the low dose of DEHP was used to investigate possible subacute toxic effects of this endocrine disrupting chemical. Adverse effects of various phthalates (including DEHP) on bone formation are studied mainly during their long-term intake, but it is also interesting to see how these endocrine disruptors affect bone microstructure and function after subacute administration during shortterm exposure. It is necessary to highlight the main limitation of our study - the analysis was carried out only one control and one experimental animal. Because of that, our results are indicative only and we can only hypothesize to differences due to exposure to DEHP. Results from the macroscopic analysis of femoral bones show the reduction of length and increase of weight in the DEHP-exposed individual compared to the control one. Because of a casuistic approach, we can only hypothesize to differences due to exposure to DEHP. In the study of Bielanowicz et al. (2016), reduced growth of femur of DBP (di-n-butyl phthalate)exposed mice was indicated by a lower volume of bone marrow (DBP dose 100 and $250 \mathrm{mg} / \mathrm{kg} /$ day). Shortened femoral bones in this study were observed at a dose of $500 \mathrm{mg} / \mathrm{kg} / \mathrm{day}$ of DBP. Bastos Sales et al. (2018) recorded higher weight of right femurs of female mice exposed to DEHP $(0.018-555.6 \mathrm{mg} / \mathrm{kg} / \mathrm{day})$. These results correspond to the findings obtained in our study.

The results of the qualitative analysis of the control sample are in accordance with several studies (Enlow and Brown, 1956; Treuting and Dintzis, 2012; Šarocká et al., 2016) however, different chemicals have been studied. On the other hand, in our study the exposure to DEHP leads to absence of non-vascular bone tissue and presence of resorption lacunae in endosteal surface (pars lateralis). The bone as a dynamic tissue is constantly reorganized by osteoclasts and osteoblasts due to various stress stimuli (Rodan, 1992). Hormones (e.g., testosterone, estrogen and cortisol) affect the bone synthesis and resorption and thus osteoblasts and osteoclasts functions. Due to this fact, estrogen-like endocrine disruptors (phthalates included) could be possibly related to the lower bone mass or affect the process of bone remodeling or formation (Agas et al., 2013). Simultaneously, Emerton et al. (2010) state, that the increased osteocyte apoptosis caused by loss of estrogens is regional, rather than uniform. In the bone cortex, the apoptotic osteocytes' location is tightly correlated with the areas where endocortical resorption is subsequently activated.

Sabbieti et al. (2009) recorded lower bone mineral density (BMD) of mice and rats as a result of inhibitory effect of phthalates on osteoblasts. According to study of Mi and Min (2014), long-term exposure to DEHP in the environment can negatively affect the bone homeostasis and BMD of menopausal women. On the contrary, DeFlorio-Barker and Turyk (2016) did not find the connection between DEHP (or its metabolites) and BMD. Moreover, in study by Chiu et al. (2018) state the daily dose of 1,10 and $100 \mathrm{mg} / \mathrm{kg}$ b.w. of DEHP during 8 weeks did not affect the BMD of mice. Authors found the DEHP and its metabolite MEHP can inhibit mineralization in cultivated stem cells of bone marrow in 10 and $100 \mu \mathrm{M}$ without cytotoxicity and disturb the balance between osteoblastogenesis and adipogenesis. Choi and Cho (2019) declare that the low dose exposure to DEHP in ovariectomized mice led to significantly lower levels of markers of bone formation while the markers of bone resorption significantly increased. These findings are consistent with our preliminary results in the context of changes observed in bone tissue, but it is necessary to take into account that our findings are based on the observation of only one animal. Despite evident differences in qualitative characteristics of the compact bone, in quantitative analysis the subacute oral administration of DEHP had no effect on the size of Haversian canals and osteons. Measured parameters of control animal in our study reached lower values comparing the 12 -weeks old Swiss mice (Šarocká et al., 2016). We assume the discrepancy could be caused by different age. 
Analyses conducted in our study did not record significant differences in the size of Haversian canals and osteons between the femoral bones of control and DEHP exposed animal. Blood vessels passing through each Haversian canal provide the necessary supplements to the bone cells. These blood vessels can react to any functional change and adapt their structure (vascular remodeling) (Pries $\boldsymbol{e t}$ al., 2005). VEGF (vascular endothelial growth factor) is important cytokine regulating angiogenesis in various physiological and pathological processes (Liang $\boldsymbol{e t}$ al., 2018). Some studies hypothesize on the disrupting effect of phthalates during angiogenesis. However, their data are focused mainly on tumor angiogenesis (Romani et al., 2014). Of course, in our study, the small sample size could affect the reliability of a survey's results because it leads to a higher variability.

According to studies (Hanahan, 1997; Thurston, 2002), the angiogenesispromoting factors (include VEGF, bFGF (basic fibroblast growth factor), ANG (angiogenin), PDGF (platelet-derived growth factor), TGF- $\beta$ (transforming growth factor- $\beta$ ) and EGF (epidermal growth factor)) and angiogenesis-inhibiting factors (angiostatin, endostatin and platelet factor-4, etc.) mutually regulated the growth of blood vessels delicately under physiological conditions. However, disequilibrium undesirably led to pathological angiogenesis. In study by Ferguson et al. (2015), associations between urinary metabolites of DEHP and decreased $\mathrm{PlGF}$, and increase in the ratio of soluble fms-like tyrosine kinase 1 (sFlt-1) to placental growth factor were observed. Study of Buteau-Lozano et al. (2008) proved the effect of various xenoestrogens (including DEHP) on the expression of VEGF in in vitro study of MELN cells delivered from breast cancer cells. Authors observed a stimulatory effect of DEHP on VEGF and, consequently, on angiogenesis and tumor progression. Liang et al. (2018) observed the lowered expression mRNA of VEGF and VEGF-2 in the pulmonary alveoli of young rats exposed to DEHP for 14 weeks period. Authors assume the effect of DEHP on the VEGF signal pathway led to the retarded growth and development of pulmonary alveoli. Although these findings point to potential adverse consequences for pregnancy or carcinogenesis in the context of angiogenic disruption by DEHP exposure, it could be also linked to our findings. DEHP has anti-androgenic and estrogenic effect, and its target is the estrogen receptor (ER) that is related to the induction of VEGF (Zhang et al., 2002). Therefore, the effect of this phthalate on the angiogenesis of the bone tissue can also be expected in the case of a study performed on a larger sample.

Collagen fibers and crystals of hydroxyapatite are the main components of osteons (Ascenzi et al., 2006; Arhatari et al., 2011). Bhat et al. (2013) found that DEHP induces the reduction of bone formation by reducing the collagen expression in rats after 21 days of exposure. We assume the insignificant differences recorded in our study could be caused by the low dose of DEHP, shorter exposure period, or by the different techniques of administration of DEHP, as well as animal group size. Those results should be seen as pilot research findings and cannot be generalized based on this study alone.

Possible changes in the behavior of DEHP-exposed mouse observed as a side effect of this study showed interesting results. Decreased appetite and lowered average weight observed in DEHP-exposed animal was also recorded by various authors (Gray et al., 1977; Park et al., 2002). After taking into account coprophage, we hypothesize that this form of behavior had evolved in response to changes in the digestive tract following DEHP exposure, but further study performed on a larger sample is needed. According to Ebino (1993), coprophagy is part of innate behavior important for maintaining the intestinal microflora. Oishi (1994) states this behavior appears mostly due to vitamin B12 avitaminosis that is necessary for spermatogenesis and hematopoiesis. DEHP exposure also causes hepatotoxicity (Lo et al., 2014) and testicular toxicity (Oishi, 1994). We assume that this behavior can point to the negative effect of DEHP, whether on intestinal microflora, or processes connected to resorption and transformation of vitamin B12.

\section{CONCLUSION}

Methods and scenarios mentioned in our study offer hypotheses that have not been researched yet and which are necessary to be verified on the larger animal groups. This step was affected by the pandemic situation. Further study is needed to elucidate our findings of bone health parameters. Our study supports the hypothesis about the negative impact of the DEHP exposure on bone tissue. Oral administration of DEHP at sublethal dose for 15 days caused significant changes in macroscopic characteristics of the compact bone tissue in a male mouse Conducting microscopic qualitative analysis, we observed the presence of resorption lacunae and the absence of non-vascular and primary vascular radial bone tissue of the experimental mouse. This result supports the hypothesis of the interfering effect of DEHP on osteoblastogenesis and angiogenesis. The microscopic quantitative analysis did not show any significant differences in measured parameters of Haversian canals and osteons of both individuals. We assume, the effect of DEHP on compact bone tissue depends on the dose and duration of phthalate exposure. Our study provides only initial information related to DEHP's impact on femoral bone microstructure and behavior in an anima model. A larger research sample, systematic approach, testing of different concentrations, and different phthalate diesters may provide more accurate results and contribute to the knowledge of the effect of phthalates on qualitative and quantitative. These findings have to be verified on large samples, to increase insights into bone microstructural changes after the application of various endocrine disruptors.

\section{REFERENCES}

Agas, D.; Sabbieti, M.G.; Marchetti, L. Endocrine disruptors and bone metabolism. Arch Toxicol. 2013, 87(4), 735-751. http://dx.doi.org/10.1007/s00204-012-0988-y Almeida, M.; Laurent, M.R.; Dubois, V.; Claessens, F.; O'Brien, C.A.; Bouillon, R.; Vanderschueren, D.; Manolagas, S.C. Estrogens and androgens in skeletal physiology and pathophysiology. Physiol Rev. 2017, 97(1),135-187. http://dx.doi.org/10.1152/physrev.00033.2015

Arhatari, B.D.; Cooper, D.M.L.; Thomas, C.D.L.; Clement, J.G.; Peele, A.G. Imaging the 3D structure of secondary osteons in human cortical bone using phaseretrieval tomography. Phys Med Biol. 2011, 56(16), 5265-5274. http://dx.doi.org/10.1088/0031-9155/56/16/012

Ascenzi, M.G.; Lomovtsev, A. Collagen orientation patterns in human secondary osteons, quantified in the radial direction by confocal microscopy. J Struct Biol. 2006, 153(1), 14-30. http://dx.doi.org/10.1016/j.jsb.2005.08.007

Barakat, R.; Lin, P.C.P.; Rattan, S.; Brehm, E.; Canniso, I.F.; Abosalum, M.E.; Flaws, J.A.; Hess, R.; Ko, CH. Prenatal exposure to DEHP induces premature reproductive senescence in male mice. Toxicol Sci. 2017, 156(1), 96-108. http://dx.doi.org/10.1093/toxsci/kfw248

Bastos Sales, L.; van Esterik, J.C.J.; Hodemaekers, H.M.; Lamoree, M.H.; Hamers, T.; van der Ven, L.T.M.; Legler, J. Analysis of Lipid Metabolism, Immune Function, and Neurobehavior in Adult C57BL/6JxFVB Mice After Developmental Exposure to di (2-ethylhexyl) Phthalate. Front Endocrinol (Lausanne). 2018, 9 683. http://dx.doi.org/10.3389/fendo.2018.00684

Bhat, F.A.; Ramajayam, G.; Parameswari, S.; Vignesh, R.C.; Karthikeyan, S.; Senthilkumar, K.; Karthikeyan, G.D.; Balasubramanian, K.; Arunakaran, J.; Srinivasan, N. Di 2-ethyl hexyl phthalate affects differentiation and matrix mineralization of rat calvarial osteoblasts--in vitro. Toxicol In Vitro. 2013, 27(1), 250-256. http://dx.doi.org/10.1016/j.tiv.2012.09.003

Bielanowicz, A.; Johnson, R.W.; Goh, H.; Moody, S.C.; Poulton, I.J.; Croce, N.; Loveland, K.L.; Hedger, M.P.; Sims, N.A.; Itman, C. Prepubertal Di-n-butyl phthalate exposure alters sertoli and leydig cell function and lowers bone density in adult male mice. Endocrinology. 2016, 157(7), 2595-2603. http://dx.doi.org/10.1210/en.2015-1936

Buteau-Lozano, H.; Velasco, G.; Cristofari, M.; Balaguer, P.; Perrot-Applanat, M. Xenoestrogens modulate vascular endothelial growth factor secretion in breast cancer cells through an estrogen receptor-dependent mechanism. J Endocrinol. 2008, 196(2), 399-412. http://dx.doi.org/ http://dx.doi.org/10.1677/JOE-07-0198 Chiu, C.Y.; Sun, S.C.; Chiang, C.K.; Wang, C.C.; Chan, D.C.; Chen, H.J.; Liu, S.H.; Yang, R.S. Plasticizer di(2-ethylhexyl)phthalate interferes with osteoblastogenesis and adipogenesis in a mouse model. J Orthop Res. 2018, 36(4), 1124-1134. http://dx.doi.org/10.1002/jor.23740

Choi, J.I.; Cho, H.H. Effects of Di(2-ethylhexyl) phthalate on Bone Metabolism in Ovariectomized Mice. J Bone Metab. 2019, 26(3),169-177. http://dx.doi.org/10.11005/jbm.2019.26.3.169

DeFlorio-Barker, S.A.; Turyk, M.E. Associations between bone mineral density and urinary phthalate metabolites among post-menopausal women: A crosssectional study of NHANES data 2005-2010. Int J Environ Health Res. 2016, 26(3), 326-345. http://dx.doi.org/10.1080/09603123.2015.1111312

Degroote, S.; Hunting, D.; Sébire, G.; Takser, L. Autistic-like traits in Lewis rats exposed perinatally to a mixture of common endocrine disruptors. Endocr Disruptors. 2014, 2(1), e976123. https://doi.org/10.4161/23273747.2014.976123 Dong, X.W.; Yao, S.Q.; Wu, H.Y.; Zhang, Y.B.; Wang, CH.; Na, X.L., Wu, W.D. Urine Metabonomic Analysis of Interventions Effect of Soy Isoflavones on Rats Exposed to Di-(2-ethylhexyl) Phthalate. Biomed Environ Sci. 2020, 33(2), 77-88. http://dx.doi.org/10.3967/bes2020.012

EFSA Panel on Food Contact Materials, Enzymes and Processing Aids (CEP); Silano, V.; Barat Baviera, J.M.; Bolognesi, C.; Chesson, A.; Cocconcelli, P.S.; Crebelli, R.; Gott, D.M.; Grob, K.; Lampi, E.; Mortensen, A.; Rivière, G.; Steffensen, I.L.; Tlustos, C.; Van Loveren, H.; Vernis, L.; Zorn, H.; Cravedi, J.P.; Fortes, C.; Tavares Poças, M.F.; Waalkens-Berendsen, I.; Wölfle, D.; Arcella, D.; Cascio, C.; Castoldi, A.F.; Volk, K.; Castle, L. Update of the risk assessment of dibutylphthalate (DBP), butyl-benzyl-phthalate (BBP), bis(2-ethylhexyl)phthalate (DEHP), di-isononylphthalate (DINP) and di-isodecylphthalate (DIDP) for use in food contact materials. EFSA J. 2019, 17(12) http://dx.doi.org/10.2903/j.efsa.2019.5838

Ebino, K.Y. Studies on coprophagy in experimental animals. Jikken Dobutsu. 1993, 42(1), 1-9. http://dx.doi.org/10.1538/expanim1978.42.1_1

Eljezi, T.; Pinta, P.; Richard, D.; Pinguet, J.; Chezal, J.M.; Chagnon, M.C.; Sautou, V.; Grimandi, G.; Moreau, E. In vitro cytotoxic effects of DEHP-alternative plasticizers and their primary metabolites on a L929 cell line. Chemosphere. 2017, 173, 452-459. http://dx.doi.org/10.1016/j.chemosphere.2017.01.026

Emerton, K.B.; Hu, B.; Woo, A.A.; Sinofsky, A.; Hernandez, C.; Majeska, R.J.; Jepsen, K.J.; Schaffler, M.B. Osteocyte apoptosis and control of bone resorption following ovariectomy in mice. Bone. 2010, 46(3), 577-583. http://dx.doi.org/10.1016/j.bone.2009.11.006 
Enlow, D.H.; Brown, S.O. Comparative histological study of fossil and recent bone tissue. Part I. . Texas J Scien . 1956, 8, 405-412.

Ernst, J.; Grabiec, U.; Falk, K.; Dehghani, F.; Schaedlich, K. The endocrine disruptor DEHP and the ECS: Analysis of a possible crosstalk. Endocr Connect. 2020, 9(2), 101-110. http://dx.doi.org/10.1530/EC-19-0548

Fan, J.; Cai, S.; Mi, S.; Chen, H.; Chen, D.; Fan, C.; Sun, L.; Li, Y. Association of urinary phthalate metabolites with osteoarthritis in American adults: Results from the national health and nutrition examination survey 2003 e 2014. Chemosphere. 2020, 128807. https://doi.org/10.1016/j.chemosphere.2020.128807

Ferguson, K.K.; McElrath, T.F.; Cantonwine, D.E.; Mukherjee, B.; Meeker, J.D. Phthalate metabolites and bisphenol-A in association with circulating angiogenic biomarkers across pregnancy. Placenta. 2015, 36(6), 699-703. https://doi.org/10.1016/j.placenta.2015.04.002

Gladuhsew, J.M. Problems of the histological investigation of the bone in forensic medicine. Sudebnomed Exp. 1964, 7, 23-26.

Gray, T.J.B.; Butterworth, K.R.; Gaunt, I.F.; Grasso, P.; Gangolli, S.D. Short-term toxicity study of di-(2-ethylhexyl) phthalate in rats. Food Cosmet Toxicol. 1977, 15(5), 389-399. https://doi.org/10.1016/S0015-6264(77)80003-5

Hanahan, D. Signaling vascular morphogenesis and maintenance. Science. 1997, 277(5322), 48-50. http://dx.doi.org/10.1126/science.277.5322.48

Hannon, P.R.; Niermann, S.; Flaws, J.A. Acute Exposure to Di(2-Ethylhexyl) Phthalate in Adulthood Causes Adverse Reproductive Outcomes Later in Life and Accelerates Reproductive Aging in Female Mice. Toxicol Sci. 2016, 150(1), 97 108. http://dx.doi.org/10.1093/toxsci/kfv317

Haynes, W.M. CRC Handbook of Chemistry and Physics, 95th ed.; CRC Press: 2014

Herrero, Ó.; Morcillo, G.; Planelló, R. Transcriptional deregulation of genetic biomarkers in Chironomus riparius larvae exposed to ecologically relevan concentrations of di(2-ethylhexyl) phthalate (DEHP). PLoS One. 2017, 12(2):e0171719. https://doi.org/10.1371/journal.pone.0171719

Hlisníková, H.; Petrovičová, I.; Kolena, B.; Šidlovská, M.; Sirotkin, A. Effects and mechanisms of phthalates' action on reproductive processes and reproductive health: A literature review. Int J Environ Res Public Health. 2020, 17(18), 1 37. https://doi.org/10.3390/ijerph17186811

Kamijo, Y.; Hora, K.; Nakajima, T.; Kono, K.; takahasi, K.; Ito, Y.; Higuchi, M.; Kiyosawa, K.; Shigematsu, H.; Gonzalez, F.J.; Aoyamma, T. Peroxisome proliferator-activated receptor $\alpha$ protects against glomerulonephritis induced by long-term exposure to the plasticizer di-(2-ethylhexyl) phthalate. J Am Soc Nephrol. 2007, 18(1), 176-188. http://dx.doi.org/10.1681/ASN.2006060597

Kanno, S.; Hirano, S.; Kayama, F. Effects of phytoestrogens and environmental estrogens on osteoblastic differentiation in MC3T3-E1 cells. Toxicology. 2004 196(1-2), 137-145. http://dx.doi.org/10.1016/j.tox.2003.12.002

Koch, H.M.; Preuss, R.; Angerer, J.; Foster, P.; Sharpe, R.; Toppari, J. Di(2ethylhexyl) phthalate (DEHP): Human metabolism and internal exposure - An update and latest results. In: International Journal of Andrology. 2006, 29, 155165. http://dx.doi.org/10.1111/j.1365-2605.2005.00607.x

Kousteni, S.; Chen, J.R.; Bellido, T.; Han, L.; Ali, A.A.; O'Brien, C.A.; Plotkin, L.; Fu, Q.; Mancino, A.T.; Wen, Y.; Vertino, A.M.; Powers, C.C.; Stewart, S.A. Ebert, R.; Parfitt, A.M.; Weinstein, R.S.; Jilka, R.L.; Manolagas, S.C. Reversal of bone loss in mice by nongenotropic signaling of sex steroids. Science. 2002 298(5594), 843-846. http://dx.doi.org/10.1126/science.1074935

Langford, D.J.; Bailey, A.L.; Chanda, M.L.; Clarke, S.E.; Drummond, T.E.; Echols, S.; Glick, S.; Ingrao, J.; Klassen-Ross, T.; Lacroix-Fralish, M.L.; Matsumiya, L.; Sorge, R.E.; Sotocinal, S.G.; Tabaka, J.M.; Wong, D.; van den Maagdenberg, A.M.; Ferrari, M.D.; Craig, K.D.; Mogil, J.S. Coding of facial expressions of pain in the laboratory mouse. Nat Methods. 2010, 7(6), 447-449. http://dx.doi.org/10.1038/nmeth.1455

Liang, Z.J.; Wu, Q.P.; Chen, B.T.; Lin, Z. L.; Lin, J.; Chen, S.Q. Postnata hyperoxia or DEHP exposure leads to growth restriction and delayed lung development in newborn rats. Pediatr Neonatol. 2018, 59(1), 24-30. http://dx.doi.org/10.1016/j.pedneo.2016.11.002

Lo, D.; Wang, Y.T.; Wu, M.C. Hepatoprotective effect of silymarin on di(2ethylhexyl)phthalate (DEHP) induced injury in liver FL83B cells. Environ Toxico Pharmacol. 2014, 38(1), 112-118. http://dx.doi.org/10.1016/j.etap.2014.05.005 Martiniaková, M.; Grosskopf, B.; Omelka, R.; Vondráková, M.; Bauerová, M. Differences among species in compact bone tissue microstructure of mammalian skeleton: Use of a discriminant function analysis for species identification. $J$ Forensic Sci. 2006, 51(6), 1235-1239. http://dx.doi.org/10.1111/j.15564029.2006.00260.X

Mi, K.B.; Min, J.Y. Urinary phthalate metabolites and the risk of low bone mineral density and osteoporosis in older women. J Clin Endocrinol Metab. 2014, 99(10), E1997-E2003. http://dx.doi.org/10.1210/jc.2014-2279

Oishi, S. Prevention of di(2-ethylhexyl) phthalate-induced testicular atrophy in rats by Co-administration of the vitamin B12 derivative adenosylcobalamin. Arch Environ Contam Toxicol. 1994, 26(4), 497-503. http://dx.doi.org/10.1007/BF00214153

Park, J.D.; Habeebu, S.S.M.; Klaassen, C.D. Testicular toxicity of di-(2ethylhexyl)phthalate in young Sprague-Dawley rats. Toxicology. 2002, 171(2-3), 105-115. http://dx.doi.org/10.1016/s0300-483x(01)00567-4
Park, C.; Lee, J.; Kong, B.; Park, J.; Song, H.; Choi, K.; Guon, T.; Lee, Y. The effects of bisphenol A, benzyl butyl phthalate, and di(2-ethylhexyl) phthalate on estrogen receptor alpha in estrogen receptor-positive cells under hypoxia. Environ Pollut. 2019, 248, 774-781. http://dx.doi.org/10.1016/j.envpol.2019.02.069

Pries, A.R.; Reglin, B.; Secomb, T.W. Remodeling of blood vessels: Responses of diameter and wall thickness to hemodynamic and metabolic stimuli. Hypertension 2005, 46(4), 725-731. http://dx.doi.org/10.1161/01.HYP.0000184428.16429.be

Rämsch, R.; Zerndt, B. Vergleichende Untersuchungen der Haverrschen Kanäle zwischen Menschen und Haustieren. Arch. Kriminol. 1963, 131, 74-87.

Richardson, K.A.; Hannon, P.R.; Johnson-Walker, Y.J.; Myint, M.S.; Flaws, J.A Nowak, R.A. Di (2-ethylhexyl) phthalate (DEHP) alters proliferation and uterine gland numbers in the uteri of adult exposed mice. Reprod Toxicol. 2018, 77, 7079. http://dx.doi.org/10.1016/j.reprotox.2018.01.006

Ricqles, A.J.; Meunier, F.; Castanet, J.; Francillon-Vieullot, H. Comparative Microstructure of Bone. In: Bone Matrix and Bone Specific Products Hall BK $(E d)$ Bone 3,. CRC Press, Boca Raton; 1991.

Rodan, G.A. Introduction to bone biology. Bone. 1992, 13, S3-S6 https://doi.org/10.1016/S8756-3282(09)80003-3

Romani, F.; Tropea, A.; Scarinci, E.; Federico, A.; Dello Russo, C.; Lisi, L.; Catino, S.; Lanzone, A.; Apa, R. Endocrine disruptors and human reproductive failure: The in vitro effect of phthalates on human luteal cells. Fertil Steril. 2014 102(3), 831-837. http://dx.doi.org/10.1016/j.fertnstert.2014.05.041

Rowdhwal, S.S.S.; Chen, J. Toxic Effects of Di-2-ethylhexyl Phthalate: An Overview. Biomed Res Int. 2018, Article ID 1750368, 10p http://dx.doi.org/10.1155/2018/1750368

Rusyn, I.; Peters, J.; Cunningham, M. Modes of action and species-specific effects of di-(2-ethylhexyl)phthalate in the liver. Crit Rev Toxicol. 2006, 36(5), 459-479. http://dx.doi.org/10.1080/10408440600779065

Sabbieti, M.G.; Agas, D.; Santoni, G.; Materazzi, S.; Menghi, G.; Marchetti, L. Involvement of p53 in phthalate effects on mouse and rat osteoblasts. $J$ Cell Biochem. 2009, 107(2), 316-327. http://dx.doi.org/10.1002/jcb.22127

Schaedlich, K.; Gebauer, S.; Hunger, L.; Beier, L.S.; Koch, H.M.; Wabitsch, M.; Fischer, B.; Ernst, J. DEHP deregulates adipokine levels and impairs fatty acid storage in human SGBS-adipocytes. Sci Rep. 2018, 8(1), 1-14 http://dx.doi.org/10.1038/s41598-018-21800-4

Šarocká, A.; Babosová, R.; Kováčová, V.; Šranko, P.; Omelka, R.; Kapusta, E.; Goc, Z.; Formicki, G.; Martiniaková, M. The effect of subacute exposure to acrylamide on femoral bone microstructure in laboratory mice. Polish J Environ Stud. 2016, 25(6), 2711-2716. https://doi.org/10.15244/pjoes/63729

Thurston, G. Complementary actions of VEGF and Angiopoietin-1 on blood vessel growth and leakage. J Anat. 2002, 200(6), 575-580 http://dx.doi.org/10.1046/j.1469-7580.2002.00061.x

Tomkinson, A.; Reeve, J.; Shaw, R.W.; Noble, B.S. The Death of Osteocytes via Apoptosis Accompanies Estrogen Withdrawal in Human Bone. J Clin Endocrinol Metab. 1997, 82(9), 3128-3135. http://dx.doi.org/10.1210/jcem.82.9.4200

Treuting P.M., Dintzis S.M. Comparative Anatomy and Histology - 2nd Edition Comparative Anatomy and Histology a Mouse and Human Atlas. Oxford, UK.; 2012

Tripathi, A.; Pandey, V.; Sahu, A.N.; Singh, A.; Dubey, P.K. Di-(2-ethylhexyl) phthalate (DEHP) inhibits steroidogenesis and induces mitochondria-ROS mediated apoptosis in rat ovarian granulosa cells. Toxicol Res (Camb). 2019, 8(3), 381-394. http://dx.doi.org/10.1039/C8TX00263K

US Environmental Protection Agency. Atlas Document for: Phthalate Esters.; 1980. Accessed December 12, 2021

Vandenput, L.; Mellström, D.; Kindmark, A.; Johansson, H.; Lorentzon, M.; Leung, J.; Redlund-Johnell, I.; Rosengren, B.E.; Karlsson, M.K.; Wang, Y.X.; Kwok, T.; Ohlsson, C. High Serum SHBG Predicts Incident Vertebral Fractures in Elderly Men. J Bone Miner Res. 2016, 31(3), 683-689. http://dx.doi.org/10.1002/jbmr.2718

Zhang, S.; Mo, J.; Wang, Y.; Ni, C.; Li, X.; Zhu, Q.; Ge, R.S. Endocrine disruptors of inhibiting testicular 3 $\beta$-hydroxysteroid dehydrogenase. Chem Biol Interact. 2019, 303, 90-97. http://dx.doi.org/10.1016/j.cbi.2019.02.027 